Vol. 16 No. 1 - April 2016

\title{
An Analysis of The Old Man and the Sea in Christian, Universal and Buddhist Perspectives
}

\author{
Amporn Sa-ngiamwibool \\ School of Liberal Arts, Shinawatra University, Thailand \\ amporn_kai@yahoo.com
}

\begin{abstract}
Religion and literature share universal senses that touch human mind. The Old Man and the Sea by Ernest Hemingway, a Pulitzer-award and-Nobel-prize winner, which is full of Christianity symbols and allusions, is selected to verify this universality, with three specific purposes which aimed to analyze and draw out: 1) Christian symbols and allusions, 2) universal senses of life, and 3) Buddhist essence in the novella. The analysis revealed these findings. All symbols and allusions relate to Christ. The attempt to fight against inevitable destiny that is a universal and natural order of life touches the mind. The novella implicated two cores of Buddhist essence: the four noble truths and the eightfold path. It could be concluded that the line between literature and religion share universality which lies in human mind, regardless of religious beliefs.
\end{abstract}

Key words: Christian, universal, Buddhist perspectives.

\section{Introduction}

Prior research on The Old Man and the Sea is mostly based on literary and related perspectives. Almost all of the studies deal with the life of the author Hemingway and the interpretations of The Old Man and the Sea. Among those studies were Bloom (1999), Jobes (1968), Bake (1969), Stephens et al. (2013), Justus (1983), Brenner (1983) and Murphy (1999). The study of the novella from religious perspectives is scanty and even scantier is a study from Buddhist perspectives. The reason for this might be a result of the fact that this novella is based on Christianity and people believe that it is impossible to cross the line between the two worlds. In fact, literature and religions come from the same world within our mind. The thin line between these two worlds is in fact a mirage. Differences among religions are therefore illusions of reality. One religion might differ from other religions in practices and details but all religions, at least, share social and individual functions. Socially, they inculcate social virtues, are agents of socialization and promote social solidarity. Individually, they provide mental peace and strengthen self-confidence. From social and individual perspectives, literature shares the same functions as religion. Both literature and religion come from the world within us and the world within us is universal. The position of this study is therefore based on the notion that literature and religion share universal senses that lie within us.

However, it is necessary to specifically verify this in details. The Old Man and the Sea is selected for the purpose of this study. It is generally accepted that The Old Man and the $\mathrm{Sea}$ is a Christianity-based novella. Numerous Christian symbols are embedded in all elements of this novella. It, however, reveals essences which are universal and natural to human mind, regardless of religious differences. This universal novella, therefore, lies beyond boundary and this quality encourages subtle interpretation by readers of other religions to overcome the thin line. The Old Man and the Sea can strengthen the notion that the lines between literature and 
religions or among religions are extremely fragile and easily breakable.

In an attempt to verify this notion that literature and religion share universality which touches human mind, three research questions are asked:

1. What are Christian symbols and allusions in The Old Man and the Sea?

2. What universal senses of life are revealed in this novella?

3. What Buddhist essences are implicated in the novella?

This study primarily verified the issue that literature and religion are universal with three specific purposes which were to draw out: 1) Christian symbols and allusions, 2) universal senses of life, and 3) Buddhist essences.

This study was a documentary interpretive analysis that integrated literary and religious approaches. The old Man and the Sea by Earnest Hemingway, a Pulitzeraward and-Nobel-prize winner, was chosen as it serves the primary purpose of the study, which aimed to verify the universality of literature and religion.

The analysis began with an exploration of Christian symbols and allusions which are explicitly stated in this novella, then look at implicit universal senses of nature and life, and finally draw out Buddhist essences in this novella. Then, the results of the analysis were drawn to conclude the study.

\section{Results of the Analysis}

The results of the analysis are presented according to the research questions.

\section{Research questions 1:}

\section{What are Christian symbols and allusions in The Old Man and the Sea?}

Hemingway purposefully refers this novella to Jesus Christ explicitly and implicitly. Explicitly, all Christianity symbols and allusions in this novella are related to Christ. The protagonist, the old man or Santiago, was depicted as Christ. To illustrate this, the picture in color of the Sacred Heart of Jesus and another of the Virgin of Cobre on the wall in his house (Hemingway, 1952: 3) relates him to Christ. There are so many quotes that purposefully link the old man to Christ. For instance, "I am not religious," he said. "But I will say ten Our Fathers and ten Hail Marys that I should catch this fish, and I promise to make a pilgrimage to the Virgin of Cobre if I catch him. That is a promise." (Hemingway, 1952: 17)

Implicitly, Hemingway created a literary device to link the old man to Christ. In Christianity, Jesus Christ is the Lamb of God who takes away the sin of the world. According to Christian theology, Christ sacrificed his life for the greater glory of humankind. Like Christ, Hemingway had a plan for the old man to be sacrificed for a greater glory (i.e. honorable destiny). His plan to identify the old man to Christ was profound. He suggested the profundity of the old man's sacrifice and the glory that derives from it by literary devices. He created symbolic parallels between the old man's sacrifice and Christ's. Sacrifice is one of the themes of this novella. The most noticeably symbolic device refers to Christ's sacrifice is crucifixion imagery.

In this novella, crucifixion imagery is the most noticeable symbol that reminds readers of Christ. The crucifixion imagery recurs in several forms, thereby Hemingway purposefully created the imagery to refer to Christ. Hemingway portrays the old man as Christ by symbolic parallels which recur several times. For instance, the old man's struggling up the hill with his mast across his shoulders brings to mind the image of Christ's march toward Calvary. Also, the old man's palm cuts by his fishing line recall the readers of Christ's suffering stigmata.

More importantly, Hemingway portrays the old man as a crucified martyr like Christ. When the sharks arrive, the old man makes a noise similar to that of a man having nails driven. The position in which the old man collapses on his bed also refers him to Christ. The old man faces down with his arms out straight and the palms of his hands up remind the readers of the image of Christ suffering on the cross. 
Even in the end, on very final pages of the novella, Hemingway refers him to the most subtle and transcendental symbolic parallel to Christ's sacrifice or death, the glory of the sacrifice and his resurrection, his greatness through all these characters (the golden lions, the boy, the fish, the old man), themes of the novella and several literary devices. All these are closely related and woven meaningfully to convey the greatness of Christ's sacrifice for mankind and true greatness of mankind.

The old man's sleeping and dreams about the lions - the only dreams he has in his life - recur several times throughout the story convey transcendental messages. The images of the old man sleeping which occurs again and again throughout the story could not help the readers think of Christ's death which is a loss on one hand but a glory on the other because Christ's death is sacrifice for mankind in taking away sin from mankind. Like Christ, the old man's sleep after the loss of Marlin the fish, the most glorious creature he has ever fished in lifetime, to sharks is a loss on one hand but glory on the other because the fish proves him as the greatest fisherman.

In his sleep, he was dreaming about the golden lions - the only creatures he has dreamt about for all his life - and these golden lions symbolize his glory. This is a transcendental way that Hemingway turns loss into glory and defeat into triumph. Similarly, this is also a transcendental way that Hemingway turns death into life. Like Christ's resurrection after death, sleep in this novella symbolically refers to death and the old man's sleeping and waking up again and again refers to death and renewed life. This renewed life is referred to by other literary devices (e.g. the golden lions, the boy and the fish). The golden lions that always recur in his dreams symbolize his revival. Lions symbolize strength and strength means life or revival.

Similar to the symbolic lions which recur in his dream, the boy is symbolic in the same way and is always linked to the lions. The boy's youth symbolizes strength and strength means life or revival. More subtly, the boy is always sitting with the old man while he is sleeping and waiting for him to wake up to give him food so that the old man can live and fish. The boy as well as his youth which symbolizes strength, therefore, means life or the old man's revival. Like the golden lions which are the symbols of the old man's glorious past when he was young and full of physical strength, Hemingway presents the boy as the old man's glorious present. The food that the boy gives the old man is not only for life but also for glory.

As a fisherman, the old man is a living legend and the greatest fisherman. Fishing is the old man's life and glory. Hemingway presents fishing not as an act of killing but as an act for living. Unlike other fishermen, the old man does not fish for commercial purpose but for food. Fishing is therefore the act for living, not that of killing. That is why he gains respect from the boy who sees him as the greatest fisherman and prefers going fishing with him to learn from him to going fishing with other fishermen, including his parents. Fishing in this novella is therefore a glorious act which is done for living. The act of fishing reaches its full meaning when the old man can prove that he is worth the boy's greatest respect to him by fishing the biggest and most beautiful fish that has never been caught by other fishermen. It was the boy who gave him food to live and gain physical strength which is needed for fishing a great fish. It was the boy who encourage him to bring back his glorious past in order to prove his greatness which he finally did. The boy therefore symbolizes the old man's present glory and greatness.

To suggest this subtle and transcendental meaning which refers to the greatness of Christ more clearly, the fish that the old man can catch is described as the strongest and most magnificent creature in the ocean symbolizes the greatness and the old man can catch the creature when he was extremely weak and very old. Since the very first paragraph of the novella, the old man was described as an unlucky fisherman who is cursed to be a complete looser who is waiting for death. Every part of his body is extremely weak, except his eyes which are full of mental strength driven by his strong 
determination. This is the way that Hemingway symbolizes his true human strength that lies in his powerful and determined mind. Human mind is true greatness and the boy was invented to symbolize this true strength and respect to him whom he respects more than anyone, even his parents. By the boy's respect to the old man, he becomes a symbol of greatness of human mind.

To illustrate this subtle and transcendental meaning more clearly, Hemingway's portrait of the old man as an honorable one who lives a life to follow the true greatness in his never-yielding heart, symbolized by his never-dying hope, as suggested by the old man code of conduct that "man can be destroyed but not defeated." Despite of his aging and sickness, he still hopes that he can catch the strongest and most magnificent fish one day which he actually does at the end. The greatness of the old man's heart cannot help bringing the readers to the greatness of Christ just as the boy who, in a sense, represents mankind by his youth, looks up to the old man with his greatest respect as the greatest fisherman. The greatness that lie in these symbols - the golden lions, the boy, the fish, the old man himself - cannot help the readers to identify the old man with Christ.

These are some illustrations that suggest the transcendental greatness of Christ in this novella. The transcendental greatness of this novella does not lie only in religious implications but also in universal truth of life and nature as revealed in the findings of the next research question.

\section{Research questions 2: \\ What universal senses of life are revealed in this novella?}

A natural and universal truth that all men, regardless of differences (e.g. races, genders and others) are subject to the same eternal law is that all men are mortal. For mankind, life is constructive whereas death is destructive because life ends up with inevitable death. All men try their best to struggle against death and whatever leads to death. Therefore, for mankind, any struggles against death are honorable. These struggles in a broader sense are the struggles against nature and the universal law of nature which eventually end with inevitable defeat or death. But these destined struggles are honorable for the reason that they transcend destructive defeat or death to a dignified destiny. These struggles therefore become the greatest honor of mankind. All men, regardless of races and religions, acknowledge the dignified destiny as the most valuable goal in life that is worth struggle for.

The Old Man and the Sea reveals this universal sense that all men share. It is a tale of an old fisherman who struggles against inevitable defeat or death. He refuses to give up at every turn even though he acknowledges that his fight is useless. The old man's struggle against defeat or death touches every one because all men are subject to this same natural law of death. He will be eventually destroyed at the end but never defeats. He is therefore presented as a hero and this heroic quality touches the readers' mind. Every one shares the universal sense that man is born to be destroyed, but not defeated.

This novella repeats this universal sense that man should not be defeated although man will be eventually destroyed at the end by this natural law of life because it is human greatness not to be defeated. The old man is exemplified as a model of the struggle. From the outset of the novella, the old man is characterized as someone struggling against defeat, symbolizing by the sail of his skiff which looks like "the flag of permanent defeat." (Hemingway, 1952: 1)

He was an old man who fished alone in a skiff in the Gulf Stream and he had gone eighty-four days now without taking a fish. In the first forty days a boy had been with him. But after forty days without a fish the boy's parents had told him that the old man was now definitely and finally salao, which is the worst form of unlucky, and the boy had gone at their orders in another boat which caught three good fish the first week. It made the boy sad to see the old man come in each day with his skiff empty and he always went down to 
help him carry either the coiled lines or the gaff and harpoon and the sail that was furled around the mast. The sail was patched with flour sacks and, furled, it looked like the flag of permanent defeat. (Hemingway, 1952: 1)

In this novella, the portrait of the old man's defeat is permanent and inevitable like death. He was considered as the unluckiest fisherman. He is alone and isolated. His only friend is the boy who is later taken away to another lucky boat by his parents. He is very old and poor. He can survive by the food from the boy. Even though he has gone eighty-four days without catching a fish and will soon pass his own record of eighty-seven days, he never gives up his hopes that he will catch a big fish one day. He never gives up, no matter what happens to him and this determination eventually leads him to success which turns him from a permanent defeat to an honorable defeat.

Hemingway purposefully conveys this message in this novella. As the readers acknowledge that, despite of his bad luck or flaw, the old man emerges as a hero. His exhibiting terrific determination, pride, bravery, strength, and moral codes of conduct are the qualities that a hero usually possesses. The qualities, especially strong determination, motivate a hero to greatness. In this novella, the old man's determination motivates him to greatness. For him, determination becomes the source of the old man's greatest strength and he killed the magnificent and mighty marlin out of determination. His determination and his capture of the marlin then lead him to his heroic transcendence of defeat. Without a sense of determination including other heroic qualities, the old man would have been abandoned the hope to fight for his trophy capture of the most magnificent marlin that stands as proof of his dignified destiny. Also, without a sense of determination, the old man would have been able to transcend defeat, or in a broader sense destructive death, to a dignified destiny as revealed through the novella's code of conduct that man can be destroyed, but not defeated.

The Old Man and the Sea portrays a struggle against life and death which is the natural order of all living things. Buddhism is a religion that substantially deals with human suffering which is the true nature of life. In this sense, Buddhism is universal. It is therefore challenging to explore Buddhist essences implicated in the novella as detailed in the result of the next research question.

\section{Research questions 3: \\ What Buddhist essences are implicated in the novella?}

Even though The Old Man and the Sea is full of Christian symbols and allusions, a detailed analysis indicates that there are at least two most essential Buddhist disciplines which is needed for liberating mankind from human suffering revealed in this novella. They are the four noble truths and the eightfold path. These two most essential Buddhist disciplines cannot help remind the readers of universal quality of this novella which is the essence of Buddhism as well as described in the details below.

\section{The Four Noble Truths}

The core of Buddhist essences is human suffering as described as the four noble truths, consisting of Dukkha, Samudaya, Nirodha and Magga.

Dukkha or human suffering is real, natural and universal. In a lifetime, all men encounter suffering which results from numerous causes (e.g. loss, sickness, pain, failure, the impermanence of pleasure and ageing). In this novella, Hemingway's portrait of the old man is a life of suffering. In the researchers' view, the only real suffering that he has is a fear of defeat as revealed through Hemingway's code of conduct that man can be destroyed but not defeated. The other apparent sufferings are invented by Hemingway to portray to give the impression of how to transcend any suffering in life. Seemingly, the old man suffers from loss of family and from contact with the world around him. Due to his ageing, he is sick and loses physical strength which is needed for fishing. Also, he seems to be in pain and suffers from social isolation and humiliation for not capturing fish for eighty-four days. It is a humiliating failure as a fisherman. Also, 
due to his ageing, he loses his youth and only pleasure when he sailed out to Africa where he met the golden lions. This pleasure exists only in his dream and it becomes the only dream he has in his life.

Samudaya is a cause of suffering. In this novella, a few causes of the old man's suffering are his ageing and his pride to capture a big fish as a trophy for his life. Ageing is inevitable while pride motivates his life. Even though his pride is constructive, it is his cause of suffering as it drives him to struggle alone at sea for eighty-four days.

Nirodha means an end to suffering. In fact, the old man does not consider ageing as suffering for him but sees it as a normal condition of life. This normal condition of life can be a cause of suffering or an end of suffering itself because there are two kinds of suffering, either real suffering or imagined one. For the old man, ageing is not suffering. Therefore, instead of giving up which is a form of self-destruction which will result in a form of suffering, he ends his suffering by fighting against ageing to follow his pride to catch a big fish. He finally captures the most magnificent marlin. He therefore turns his failure to success and the cause of his suffering becomes the end of his suffering. In the end, he ceases to go out to that far as he satisfies himself with the most magnificent marlin and thereby his suffering ends successfully.

Magga is a path to end suffering and, to do so, one must follow the eightfold path. Surprisingly, the path that the old man ends his suffering is almost perfectly consistent with the eightfold path as described in details below.

\section{The Eightfold Path}

The eightfold path is the way to end human suffering through panna (wisdom or discernment), sila (virtue or morality) and samadhi (concentration, meditation). The eightfold path consists of samma ditthi (right understanding of the four noble truths), samma sankappa (right thinking, following the right path in life), samma vaca (right speech; no lying, criticism, condemning, gossip, harsh language), samma kammanta (right conduct by following the five precepts), samma ajiva (right livelihood, supporting yourself without harming others), samma vayama (right effort; promoting good thoughts, conquering evil thoughts), samma sati (right mindfulness; become aware of one's body, mind and feelings), and samma samadhi (right concentration, meditate to achieve a higher state of consciousness). This path can be clearly seen through the life of the old man.

The way that the old man leads his life can be analyzed by this eightfold path even though Hemingway might have no ideas at all about Buddhism. This might be a result of the fact that he was concerned about the condition of life which is also the concerns of Buddhism. (Hemingway's suicide stands a proof of his concerns about the condition of his life or life in general. The whole story of The Old Man and the Sea exemplifies the condition of suffering that is inevitable for everyone. He suggests an honorable solution for the inevitable defeat. Unfortunately, he chose to end his life otherwise.) Evidently, Hemingway and Buddhism look at human suffering as true essence of condition of life and provide practical solutions to end human suffering. Because of this, they share some similarities. The old man meaningfully exemplified the eightfold path, either intentionally or unintentionally, as described below.

Above all, the old man possesses the right understanding of the four noble truths (samma ditthi). The only human suffering (dukkha) that he faces is ageing which is inevitable. He lacks physical strength which is needed and vital for his mission to catch a big fish. He understands the cause of his suffering (i.e. lack of physical strength) rightly. He builds up a stronger determination to achieve his mission instead.

Additionally, he has the right thinking of the four noble truths (samma sankappa). He follows his right understanding of the condition of his life what is needed for his mission. The purpose he fights against ageing is not to change the condition of his life because he accepts his predetermined 
destiny. Instead, he fights against it for an honorable destiny. His thinking is therefore absolutely right.

Right thinking is conducive to right speech (samma vaca). The old man says only good things about the boy's parents even though they say otherwise about him. When he talks to creatures at sea, his words are full of understanding, mercy and respect to those creatures around him, even to the sharks that destroy his marlin.

Also, right thinking directs right conduct (samma kammanta). Unlike other fishermen who fish for commercial purpose, which is an evil thought, rather than for food, which is a necessity for survival, the old man fishes for survival. He has respect for fish, especially the marlin. Therefore, his fishing comes from the act of loving as revealed in his thought that "I kill you because I love you." Brenner noted the killing as respectful killing:

A symbolic character, Santiago embodies only virtues that ask for moral approval of him as an idealized Papa. He is selfless, thoughtful, courageous, durable, reliable, and, above all else, gentle. Ever thoughtful of his "brother" the marlin, at one point he wishes he "could feed the fish" (59), at another is "sorry for the fish that had nothing to eat" (75), and still later deeply grieves when the first shark mutilates the fish's beautiful body (103). He shows no anger toward the fishermen who make fun of him (11). (Brenner, 1983: 176)

Right conduct creates right livelihood (samma ajiva). The old man supports himself without harming others, especially the beloved ones. The boy's parents see him as a bad luck for not capturing fish in eighty-four day and ordered the boy to leave his boat. Even though the boy wishes to stay, the old man asks him to obey his parents. They still become good friends. The old man always returns his good wishes and gratitude to his good friends, giving the best parts of the marlin to them. As a result of a pleasant and decent livelihood he creates, all his good friends are friends indeed and in need.
Right thinking leads to right effort (samma vayama). The old man promotes good thoughts to conquer evil thoughts that are inherent to human mind. He conquers such evil thoughts by his right thinking, determination and efforts. He acknowledges that his strength is deteriorating and other people in the village look at him as a bad luck for not catching fish in eighty-four day. $\mathrm{He}$ never gives up the hope to capture a big fish at any turns. His effort reveals in his determined eyes.

Right mindfulness (samma sati) helps one to become consciously aware of body, mind and feelings. The old man is portrayed as a perfect example of right mindfulness. Two thirds of the novella reveals his high body, mind and feelings awareness of all living creatures around him while he is sailing alone at sea. His right mindfulness reveals in his rare anger and negative reaction to people and things and him.

He respects Manolin's father's decision that the boy fish with someone else after forty fishless days with Santiago. Even his dreams are innocuous, filled with mating porpoises and frolicsome, not fierce, lions. He is violent only when killing the attacking sharks. But such actions, in defense of his "brother," sanctify hostility. Finally, Manolin's adoration shows the absence of any punitiveness in Santiago's role as his substitute father. (Brenner, 1983: 176)

Lastly, right concentration (samma samadhi) refers to meditation to achieve a higher state of consciousness. Hemingway chose the sea as the scene of this novella purposefully and almost all events happen at sea. The only human being is the scene is the old man. Being alone at sea for eighty-four day symbolically refers to meditation which helps improve his awareness of body, mind and feelings. Being alone at sea for another eighty-four day or more can be nothing else but meditation to achieve a higher state of consciousness. This right concentration which helps him achieve a higher state of consciousness rewards him with the magnificent marlin. This novella conveys the message that it is worth doing meditation to achieve a higher state of consciousness to be 
in the state of the right concentration which is implicitly referred to as the key to the old man's success in the end.

The four noble truths and the eightfold path provide a path to liberation from suffering in life. As revealed in the end of the novella, the old man turns the condition of permanent defeat at the outset of the tale to honorable defeat which liberates him from all life suffering.

\section{Conclusion}

Above all, The Old Man and the Sea is a Christian novella which the author Hemingway purposefully refers to Christ. Several crucifixion symbols and allusions symbolically transcend the old man's greatness to the greatness of Christ's sacrifice for mankind.

In addition, this novella is a tale of human struggles against natural and universal truth which all men are subject to the same eternal law that all men are mortal. Any struggles against death are honorable. This novella exemplifies how to transcend death to a dignified destiny.

Lastly, two most essential Buddhist disciplines which are needed for transcending death to a dignified destiny and for liberating mankind from human suffering revealed in this novella and the four noble truths and the eightfold path. Even though the author has no intention at all to associate to Buddhism, this novella deals with the condition of life so it is inevitably deals with the essence of Buddhism.

\section{Discussion}

The finding of this study shares similarities and dissimilarities with that of Burhans (1960) in that Hemingway's vision of man is tragic. The old man was referred to Christ's sacrifice for mankind as indicated by several crucifixion symbols and allusions. Also, this tragic vision of man is consistent with Hemingway's suicide (Baker, 1969). However, the vision of man in this present study is not completely tragic. The old man in this study symbolically transcends the old man's greatness to the greatness of Christ's sacrifice for mankind. The result of this study therefore is similar to the finding of Justus (1983) that the sacrifice is not a failure but it possesses a sense of greatness. Like Murphy's Hemingway's Gentle Hunters: Contradiction or Duality? (1999), this present study perceives the duality of the old man. This study is similar to the study of Brenner (1983) that Hemingway's portrait of the old man is that of greatness and virtues which is inspired by nature, like the study of Hauser (2006). The meaning of life and death is a great problem but even greater is living a decent life led by greatness and virtues that lie in human mind as simplified by Hemingway's code that "man can be destroyed but not defeated," which transcends destined defeat to honorable defeat.

\section{References}

Baker, Carlos. Ernest Hemingway: A Life Story. New York: Scribner's, 1969.

Bloom, Harold. Ed. Ernest Hemingway's The Old Man and the Sea. Philadelphia, PA: Chelsea House, 1999.

Brennner, Gerry. Concealments in Hemingway's Works. Columbus: Ohio State University Press, 1983.

Burhans, Clinton S., Jr. "The Old Man and the Sea: Hemingway's Tragic Vision of Man." American Literature 31, 1960: 446-55.

Hauser, Marc D. Moral Minds: How Nature Designed Our Universal Sense of Right and Wrong. New York: Harper Collins, 2006.

Hemingway, Ernest. The Old Man and the Sea. New York: Charles Scribner's Sons, 1952.

Jobes, Katharine T., ed. Twentieth Century Interpretations of The Old Man and the Sea: A Collection of Critical Essays. Englewood Cliffs, NJ: Prentice Hall, 1968. 
Justus, James $H$. "The Later Fiction: Hemingway and the Aesthetics of Failure." In Ernest Hemingway: New Critical Essays. Ed. A. Robert Lee. London: Vision, 1983. 103-121. Rpt. in Bloom 125-139.

Meyers, Jeffrey. Hemingway: A Biography. London: Macmillan, 1985.

Murphy, Charlene M. "Hemingway's Gentle Hunters: Contradiction or Duality?" In Hemingway and the Natural World. Ed. Robert E. Fleming. Moscow, ID: U of Idaho P, 1999. 165-174.

Stephens, Gregory. et al. “'Out Too Far”: HalfFish, Beaten Men, and the Tenor of Masculine Grace in The Old Man and the Sea" The Hemingway Review. 32 (2), 2013: 77-94. 